\title{
Nodular lymphocyte predominant Hodgkin lymphoma
}

INSERM

\section{Source}

INSERM. (1999). Orphanet: an online rare disease and orphan drug data base. Nodular lymphocyte predominant Hodgkin lymphoma. ORPHA:86893

Nodular lymphocyte predominant Hodgkin lymphoma (NLPHL) is a rare subtype of Hodg kin lymphoma ( $\mathrm{HL}$; see this term) characterized histologically by malignant lymphocyte predominant (LP) cells and the absence of typical Hodgkin and ReedSternberg (HRS) cells. 